\title{
Mnemonics for War: Trench Art and the 86) Reconciliation of Public and Private Memory
}

Clare Whittingham, McMaster University

\begin{abstract}
The study of British First World War memorials has generated a considerable body of literature since its emergence as a scholarly field in the 1990s. Less attention has been devoted, however, to commemorative objects of a smaller and more personal character that were collected during and after 1914-1918 for display in homes and museums. This paper finds 'trench art', battlefield souvenirs and commercially produced war kitsch negotiating the gap between civilian and military experiences of war and its translation into memory. Particular consideration is given to the Imperial War Museum as representative of institutional attitudes towards this unique and still-contested category of unconventionally commemorative material.
\end{abstract}

The study of British First World War memorials has produced a considerable body of literature since its emergence as a subject of scholarly interest in the 1990s. ${ }^{1}$ Less attention has been paid, however, to the war memorabilia, mementos, battlefield souvenirs and household kitsch now commonly referred to as Trench Art. Though trophies of war were sought by private collectors and public museums well before the outbreak of hostilities in 1914,

\footnotetext{
${ }^{1}$ Modris Eksteins, Jay Winter, Alex King, Adrian Gregory and Catherine Moriarty are some of the many historians who have considered First World War memorials and commemoration practices in recent years.

Past Imperfect

14 [2008] | () |ISSN 1711-053X | eISSN 1718-4487
} 
trench art of the First World War has uniquely resisted institutional classification, challenged conventional curatorial wisdom and seldom been exhibited in public displays. Once characterized by historian George Mosse as "deceptive trivializations," view this category of variably whimsical, personal, horrifying, clever and often beautiful objects as an untapped resource for understanding how the First World War was processed by communities and individuals in physical and cultural terms.

This paper examines trench art and its conceptual position among public and private memorials of the First World War in Britain. Given the continued incidence of armed conflict today, the expressive quality of this category of objects offers valuable insight to the complexities of war and variety of lives affected by political disputes. In a more historical context, smallscale memory objects produced at the home and battle fronts helped to clarify the complexities of war for both military and civilian individuals through discreet display in domestic, private space. Amid a cultural climate of fragmentation and against the conceptual homogeneity of official war memorials, trench art manipulated memories of war into collectible yet confounding artifacts. Public memorials, including the Imperial War Museum, relied upon monumentality, austerity and simplicity in their attempt to ease public grief and fittingly commemorate 19141918. In contrast, trench art offered personal and idiosyncratic interpretations of war by manipulating physical materials directly

\footnotetext{
${ }^{2}$ Winter, "George Mosse's Comparative Cultural History" in What History Tells: George L. Mosse and the Culture of Modern Europe. Stanley G. Payne, David J. Sorkin \& John S. Tortorice, eds. (Madison: University of Wisconsin Press, 2004) 152
} 
associated with the conflict and endowing them with new symbolic meaning. Amid a wide array of public and private forms of First World War commemoration in Britain, this paper places trench art at a unique intersection between the recently developed scholarly field of memorial culture in Britain and the less familiar study of battlefield detritus. The following research also affirms 88| the significance of assembly, collection and display in constructing narratives of memory through physical objects which, though removed from their original contexts, remain laden with symbolic meaning.

\section{Fragments: The Experience of War}

Historian and anthropologist Nicholas J. Saunders' definition of armed conflict as "the transformation of matter through the agency of destruction" ${ }^{3}$ fittingly describes the physical and sensory upheaval endured by soldiers and civilians during the First World War. Fragmentation and incomprehensibility were symptomatic of combat that presented an infinite range of often confounding experiences. ${ }^{4}$ Artillery shells were central to this environment of confusion and destruction, "the defining objects...fragmenting peoples, places and institutions." Entrenchment, now so iconic of the First World War experience,

\footnotetext{
${ }^{3}$ Nicholas J. Saunders, Trench Art: Materialities and Memories of War. (Oxford: Berg Books, 2003) 1

${ }^{4}$ Stuart Sillars, Art and Survival in First World War Britain. (New York: St. Martin's Press, 1987) 1

${ }^{5}$ Saunders, "The ironic "culture of shells' in the Great War and beyond" in Matériel Culture: The archaeology of twentieth century conflict. John Schofield, William Gray Johnson and Colleen M. Beck, eds. (London: Routledge, 2002) 22
}

$$
\begin{gathered}
\text { Past Imperfect } \\
14 \text { (2008) | (C) |ISSN 1711-053X | elSSN 1718-4487 }
\end{gathered}
$$


originally developed in response to the dangers of high-explosive artillery. $58 \%$ of war casualties were caused by artillery shells deployed in nearly incomprehensible quantities, with some areas of the Western Front territory absorbing more than 1000 shell hits per square metre. ${ }^{6}$

In the process of bombardment, landscapes and men were simultaneously deconstructed to the point of being |89 unrecognizable. Human corpses fell into the surrounding environment only to be absorbed by mud and eventually incorporated in the walls of new trenchworks. ${ }^{7}$ Dugouts, camouflage and mud made it nearly impossible to distinguish men's bodies from the landscape, and 'invisibility' became a new reality of war that many men found psychologically intolerable. Artillerymen seldom spotted their human targets at close range, and could be similarly fired on from unascertainable sources. Seeing the enemy, however, was often just as troubling given their similarity to one's own men and resulting sense of confused identity. C.E. Montague lamented how "the hatred business started crumbling" ${ }^{\prime 8}$ once an enemy was spotted up close; the experience became even worse by discovering "only the usual stuffing...photographs and tobacco and bits of string and the

\footnotetext{
${ }^{6}$ Many areas remain packed with metal to this day. See Gordon Corrigan, Mud, Blood and Poppycock: Britain and the First World War. (London: Cassell, $2003)$ 116; Donovan Webster, Aftermath: The Remnants of War. (New York: Pantheon Books, 1996) 22-25; Eric J. Leed, No Man's Land: Combat and Identity in World War I. (Cambridge: University Press, 1979) 99

${ }^{7}$ Saunders, "Matter and Memory in the Landscapes of Conflict: The Western Front 1914-1999" in Contested Landscapes: Movement, Exile and Place. Barbara Bender and Margot Winer, eds. (Oxford: Berg Books, 2001) 38; also "Bodies of Metal, Shells of Memory: 'Trench Art' and the Great War Recycled" Journal of Material Culture 5:1 (2000) 56

${ }^{8}$ C.E. Montague, Disenchantment. (London: Chatto and Windus, 1922) 148 
wife's letters" $"$ in his pockets. In addition to the physical confusion between landscapes and men, perceptions of the self were also muddied in the field of battle.

Artillery reformed the relationship between human beings and technology. Disconnected from $19^{\text {th }}$ century notions of machinery as a progressive and productive force, high-explosive 90| guns and their ceaseless dispensary of ammunition rapidly became "strange, frightening and demonic." 10 Artillery brought its own unique sort of sights to battle; soldiers witnessed physical oddities like shells hovering in air, changes in the colour of atmosphere caused by explosions, and the ironically helpful utilization of empty shell cases as gas alarms. ${ }^{11}$ Battlefield matériel was constantly being transformed by sensory interpretations: shelling at night became "free fireworks displays" and helmets glistened like "curious green mushrooms" under the light of parachute flares. ${ }^{12}$ The physical devastation of monumental buildings like the Cloth Hall at Ypres and Albert Cathedral similarly offered surreal scenery produced by the machines of war. ${ }^{13}$

Metal was the defining material of the First World War; it protected men, rained down on them, preserved their food and

\footnotetext{
${ }^{9}$ Ibid, 149

${ }^{10}$ Leed, 31

${ }^{11}$ Saunders, "The ironic "culture of shells"" 27-28

${ }^{12}$ George Robb, British Culture and the First World War. (Basingstoke: Palgrave, 2002) 181; Edmund Blunden, Undertones of War. (Garden City: Doubleday, Doran \& Co. Inc., 1929) 75

13 After 1918, curious battlefield visitors were fascinated by landscapes transformed through technology, and some even expressed the ironic desire that former areas of conflict should be kept in a ruined state. See David Lloyd, Battlefield Tourism: Pilgrimage and the Commemoration of the Great War in Britain, Australia and Canada, 1919-1939. (Oxford: Berg Books, 1998) 115, 119; also How Nature Covers Up the Scars of War: Scenes of the most furious fighting in 1916, as they appear today (Mills Research Collections, c.1920)
}

$$
\begin{gathered}
\text { Past Imperfect } \\
14 \text { [2008) | @ |ISSN 1711-053X | elSSN 1718-4487 }
\end{gathered}
$$


saturated the ground with what is now often referred to as the 'iron harvest.' Its pervasive presence at the front altered perceptions of everyday materials as combatants developed a new aesthetic sense where everything, no matter how apparently humble, might have a life-saving use. Conversely, familiar items like shaving kits and dining utensils began to carry associations with ammunition and shrapnel by virtue of their shared physical composition. Fragments of military life, even objects used for mundane tasks, therefore carried associations with more destructive war implements. ${ }^{14}$ When these items were manipulated into works of trench art, they consequently indicated a variety of possible uses and maintained a constantly shifting level of symbolic importance.

Fragmentation also characterized aspects of the civilian world during and immediately after the First World War. Feelings of alienation and social disjointedness plagued servicemen on leave who had difficulty adjusting to life in England, particularly the activities of conscientious objectors. 'Civilian incomprehension' of life at the front was a common complaint, and war poets including Seigfried Sassoon and Rupert Brooke directed much of their verse against their perception of popular ignorance. $^{15}$

Civilian individuals were not entirely to blame, nor were their understandings of the war entirely homogenous; yet the home front was often informed by distorted sources. Early

\footnotetext{
${ }^{14}$ Fabio Gygi, "Shattered experiences - recycled relics: strategies of representation and the legacy of the Great War" in Matters of Conflict, 78-79

${ }^{15}$ Paul Fussell, The Great War and Modern Memory. (New York: Oxford University Press, 1975) 86-87; Robert Wohl, The Generation of 1914. (Cambridge, Massachusetts: Harvard University Press, 1979) 100 
newspapers published illustrations based upon here-say historical conventions of representing combat rather than actual information from first-hand experience. ${ }^{16}$ War kitsch available for purchase and domestic display could also be misleading in its representation of war: manufacturers of heraldic china military miniatures seldom saw their subjects in person, and the production 92) of tiny tanks, shells and soldiers in pristine white porcelain offered images from battle but "purged of blood and mud." 17

Even official war artists had difficulty fully expressing the realities of war. John Sargent's Gassed, intended for the Imperial War Museum's Hall of Remembrance, was based on observations of mustard gas patients in hospital rather than Sargent's own experience of a gas attack. ${ }^{18}$ Direct experience was no guarantee of direct representation, however, as artists who actually fought in the Great War tended to convey the experience through dreamlike imagery. Paul Nash's The Menin Road embodies the incomprehensible contrast between the artist's expectations, public understandings, and his actual experience of war. ${ }^{19}$

Social transformations and confusions of identity were also felt among the British public when the necessity of military training set enlisted friends and loved ones apart from the civilian world. $^{20}$ Military assimilation was described at the time as a death of sorts, through which new and occasionally unrecognizable

\footnotetext{
${ }^{16}$ Robb, 138

${ }^{17}$ Barbara Jones and Bill Howell, Popular Arts of the First World War. (London: Studio Vista, 1979) 25

${ }^{18}$ Richard Cork, A Bitter Truth: Avant-Garde Art and the Great War. (New Haven: Yale University Press, 1994) 221

${ }^{19}$ M.R.D. Foot, Art and War: Twentieth Century Warfare as Depicted by War Artists. (London: Headline, 1990) 20

${ }^{20}$ Leed, 17
} 
personalities formed. After some time at the front, terms like 'frigiped' and 'jumping the bags' frequently used by enlisted men remained unfamiliar to civilians. ${ }^{21}$ A sense of separation often plagued families and friends who felt the soldier's war experience as an insurmountably incomprehensible psychological boundary. ${ }^{22}$

It is also important to acknowledge that civilian and military experiences during the war were not entirely irreconcilable. Some wartime activities fostered a uniquely close relationship between civilians and soldiers, perhaps none more so than the manufacture of munitions on British soil. Lord Kitchener's Appeal claimed that arsenal employees did "their duty for their King and country in a like manner with those who have joined the Army for active service in the field," ${ }^{23}$ and women shared a particularly complex and often ironic relationship with the hundreds of thousands of artillery shells they helped to produce during the war. Making bombs was often likened to making babies, yet the products of this labour brought about far more destruction than any natural system of procreation. And while 'munitionettes' worked to increase the instruments of devastation for battle, other women employed as nurses had the task of piecing together bodies maimed by industrially produced weapons. $^{24}$

\footnotetext{
${ }^{21}$ Fussell, 179

${ }^{22}$ Those who fought at the Front often considered themselves 'a race apart' for whom civilian life could instigate alienation, loneliness and madness. See Gerard DeGroot, Blighty: British Society in the Era of the Great War. (London: Longman, 1996) 277-78

${ }^{23}$ Lord Kitchener's Appeal: 'Unless the whole Nation works with us and for us' (Mills Research Collection, pamphlets of the First World War)

${ }^{24}$ Saunders, "The ironic "culture of shells", 26

$$
\begin{gathered}
\text { Past Imperfect } \\
14 \text { [2008] | } \odot \text { |ISSN 1711-053X| |eISSN 1718-4487 }
\end{gathered}
$$
}


Though the munitionette became a popular stereotype in newspapers and magazines, munitions manufacture had its deadly side: an explosion at the Silvertown factory in London's East End killed 69 and injured 450 workers, most of whom were women, in January $1917 .^{25}$ The close and sometimes destructive relationship with technology experienced by civilian workers often paralleled 94 that of soldiers at the battle front. Munitions workers operated in environments completely surrounded by massive metal machinery where the distinction between human and machine became unclear. $^{26}$ Factory equipment brought its own set of sights and sounds, just as the sensory experience of artillery at the front: "like a flock of nightmare birds...Clang, clang, zzz, whrr. Deafening, stupefying, brain-shattering.,"27 Women could also experience intense emotions in the process of production, often in response to personal losses from the war:

Each time that she heaved one of the shell-cases from the floor on to the fixture in front of her; each time that she turned the great wheel which sent the fixture driving through the case, clearing and hollowing it to the required dimensions; each time that she measured carefully across the diameter of the top to see that the

${ }^{25}$ David Bilton, The Home Front in the Great War: Aspects of the Conflict 1914-1918. (Barnsley: Leo Cooper, 2003) 81

${ }^{26}$ A photograph of woman making shell-cases shows her dwarfed by a machine with a gear wheel as wide as she is tall; see James Bishop, The Illustrated London News Social History of the First World War. (London: Angus \& Robertson Publishers, 1982) 85

${ }^{27}$ Irene Rathbone, excerpt from We That Were Young (1932) in Beyond the Home Front: Women's Autobiographical Writing of the Two World Wars. Yvonne M. Klein, ed. (London: Macmillan Press, 1997) 87-88 Past Imperfect
14 [2008] | (C) |ISSN 1711-053X | eISSN 1718-4487 
cap would fit exactly, she sent wishes of death with the shell. ${ }^{28}$

Unfortunately, British-made shells sometimes killed British troops. Hundreds exploded prematurely at the front as the result of poor quality control under demands for swift production. ${ }^{29}$ When spent shell cases were brought home to England as war souvenirs or incorporated into trench art objects, they carried the remnants of this unpredictable and ironically destructive power.

Civilians were far from immune to the effects of war, many of which extended far beyond the geographic region of active battlefields. Aerial bombardment of targets in Britain began 21 December, 1914 over Dover and the first German bombing of London took place on 8 September, 1915. Though modest in strategic effectiveness, these events caused hundreds of casualties - mostly among children - and had a significant psychological effect on the British population. ${ }^{30}$ Occupants of the East coast came in contact with the materials of war as German sea mines began to wash up on English shores, pieces of Zeppelin wreckage were put on display in London in 1916, and a cottage industry formed in Hartlepool making souvenirs from scrap aluminium after a Zeppelin crashed nearby. ${ }^{31}$ 'Experts' hoped to reconstruct ruined ships based on their wreckage, and siezed on the amount of wood in Zeppelin construction as evidence of aluminium shortages in Germany. ${ }^{32}$ Crashes of war

\footnotetext{
${ }^{28}$ Ibid, 90

${ }^{29}$ Saunders, "The ironic "culture of shells", 24

${ }^{30}$ Bilton, 62

${ }^{31}$ Bishop, 34, 70; Saunders. Trench Art, 141

${ }^{32}$ The Great Air Raid on England Sept.3, 1916. (London: St. James Press, 1916) unnumbered
}

$$
\begin{gathered}
\text { Past Imperfect } \\
14 \text { [2008]| (C) |ISSN 1711-053X| | ISSN 1718-4487 }
\end{gathered}
$$


material at the home front became opportunities to educate engineers and boost civilian morale. Metal littered and devastated the English landscape just as it pounded Flanders into oblivion.

The War Office drew further connections between civilian and military life in their efforts to raise financial support throughout the war. A mock-up ruined Belgian town was installed 96| at Trafalgar Square to help sell War Bonds and offered a carnivalesque sense of the devastation visible along the Western Front. ${ }^{33}$ 'Tank Banks' appeared in London and other British cities as a way of encouraging contributions, increasing recruitment, and improving civilian familiarity with the latest armoured vehicles. Commercial vendors also found ways to connect the conflict with consumer goods, from Selfridges' 'War Windows' to the suggestion by Decca that civilians purchase portable gramophones to send to servicemen in the trenches. ${ }^{34}$

Fragmentation was accepted as a characteristic element of the war experience for both civilian and soldier, wherein the only hope for assembling a coherent personal and public memory lay in the recognition of broken patterns. 'Before and After the War' became a vital way of thinking about the history of nations and individuals. ${ }^{35}$ Variety was a characteristic aspect of war experiences for civilian and serviceman alike: "the boundaries of war are not fixed once and for all, because war is not a discrete entity, but something intricately lived, conceptualized, and imagined."36 Memory is and remains an ultimately subjective

\footnotetext{
${ }^{33}$ Bilton, 103

${ }^{34}$ Robb, 173

${ }^{35}$ Samuel Hynes, A War Imagined: The First World War and English Culture. (London: The Bodley Head, 1990) 433-434

${ }^{36}$ Jay Winter and Antoine Prost, The Great War in History: Debates and Controversies, 1914 to the Present. (Cambridge: University Press, 2005) 6 
experience, dependent fundamentally on the individual. The assembly and collection of commemorative objects now classified as trench art in civilian homes since 1914 fittingly responded to this sense of chronic divide and diminished the sense of disconnection engendered by war.

Physically, the presence of a dead serviceman's belongings in domestic space provided direct evidence of life at the front: many relatives spoke of a particular smell that lingered on greatcoats, papers, and other souvenirs, some of which arrived in England still caked with Flanders mud. ${ }^{37}$ For veterans, however, the placement of war souvenirs in civilian homes could be very disconcerting. A brief fad during the 1920s for dinner gongs made from old artillery shells (a functional example of trench art) stirred very different feelings among invited guests accustomed to hearing these instruments used to signal gas attacks. ${ }^{38}$ The postwar popularity of battlefield tourism among civilians seemed equally disturbing to some servicemen, who found it "a mockery to go back to the Salient, as tourists, on a summer day." 39 Collecting souvenirs was so often an element of these expeditions that a serious demand for trench art arose and supported the existence of cottage industries for its production in Europe and Britain. Many ex-servicemen also visited former battlefields in peace time, but their reaction to the souvenir market varied from appreciation to cynicism. Visiting Ypres in 1927, Gerhard Schinke was appalled with the commercialization of war, whereby

\footnotetext{
${ }^{37}$ Catherine Moriarty, “'Remnants of Patriotism': The Commemorative Representation of the Greatcoat after the First World War" Oxford Art Journal $27: 3$ (2004) 308

${ }^{38}$ Saunders, Trench Art, 70

${ }^{39}$ Ralph Hale Mottram, Ten Years Ago: Armistice and Other Memories. (London: Chatto \& Windus, 1928) 1

Past Imperfect 14 [2008] | ( ) |ISSN 1711-053X | eISSN 1718-4487
} 
"in addition to a profusion of manufactured souvenirs for sale in shops, children on the street offered to sell him rusted weapons, helmets, grenades, and tunic buttons."40 Though servicemen and civilians shared the desire to visit and explore former sites of conflict, reactions to physical remnants of war varied depending upon one's personal experience and remaining memories of war.

98| Similarly, the ritual of Armistice Day carried unique significance for the resolution of public versus private memory. Ex-serviceman Ralph Mottram recalled in 1928 that these annual ceremonies were simultaneously comforting and disturbing for different people:

[It was] all very well for the crowd below, composed of women, or those who had been children ten years before, and from whom some relative had gone, never to return. To such it was a fit and touching ceremony. To [veterans] it was different. There, across their lives, like a great scar across the face, was the War something you could neither obliterate, explain, nor turn to any useful end. ${ }^{41}$

As Armistice Day ceremonies increasingly focused on public mourning through the $1920 \mathrm{~s}$, many veterans found it more difficult to participate and find meaning in the day. ${ }^{42}$ An originally complex ritual of remembrance for the war's end, including a good deal of jubilation in 1919, gradually failed to acknowledge the variety of experiences shared among ex-

\footnotetext{
${ }^{40}$ Eksteins. "Memory and the Great War" in The Oxford Illustrated History of the First World War. Hew Strachan, ed. (Oxford: University Press, 1998) 310311

${ }^{41}$ Mottram, 173-74

${ }^{42}$ Dan Todman, The Great War: Myth and Memory. (London: Hambledon Continuum, 2005) 53
} 
servicemen. $^{43}$ Personal narratives of survival, victory, camaraderie and celebration in youth were homogenized or ignored in order to fit public norms of remembrance and grief. Collective memories of the war as a fragmentary experience turned public attention away from appreciating the nuance of personal narrative towards monolithic physical memorials with prototypical forms. The pairing of Portland stone and bronze became a standard vocabulary for hundreds of memorials constructed throughout Britain and the Commonwealth, where recurring sculptural forms forged a long-sought sense of aesthetic and symbolic consistency and delicately avoided the traits of fragmentation and confusion characteristic of preceding years. During the 'war books' boom of the late 1920s, when vocal criticism of 1914-1918 reached its peak of popularity, public forms of memorial consistently avoided the unpleasant kind of imagery conveyed by writers like Gabriel Marques and Siegfried Sassoon. Trench art objects, given their insistent variety and aesthetic irregularity, provided a counterweight for the stoicism of public memorial projects; these small-scale items must therefore be considered in the broader context of civic memory and its imagery.

\section{Remembrance: Cenotaph and Sentinel}

The First World War inspired an unprecedented wave of war memorial construction in Britain, where less than five years after the war's end, nearly every town could boast of a monument being

\footnotetext{
${ }^{43}$ Adrian Gregory, The Silence of Memory: Armistice Day, 1919-1946. (Oxford: Berg Books, 1994) 51, 65, 84

Past Imperfect 14 [2008) | @ |ISSN 1711-053X| elSSN 1718-4487
} 
planned or nearing completion to honour 1914-1918. Battlefield and burial sites overseas were also designated memorial space with rows of uniform headstones, architectural crosses, and other commemorative structures imposed upon landscapes still marked with overgrown trenches and exploded craters. The effort, resources, and public grief expended through these projects was 100 tremendous, and now sheds light on the role of trench art as a negotiator between the standardization of public memory and the idiosyncrasies of private commemoration.

The memorialization of 1914-1918 stemmed from a general need within Britain's population to order suffering and control the apparent indignity, randomness and inexplicability of suffering in war. ${ }^{44}$ Monuments and memorials in public places "[built] the war physically into post-war reality" and manifested an experience from the recent past. ${ }^{45}$ They did not, however, represent actual sights from that experience; most memorials took on an elemental, blank and austere appearance, ornamented occasionally by conventions from Classical sculpture. Edwin Lutyen's Cenotaph at Whitehall, London, simultaneously inspired and epitomized this type. One of the first war memorials to appear in England, and certainly one of the most renowned, Lutyens' Cenotaph was readily adopted as a public shrine despite anxieties initially expressed by Sir Alfred Mond that it "may be of too mournful a character as a permanent expression of the

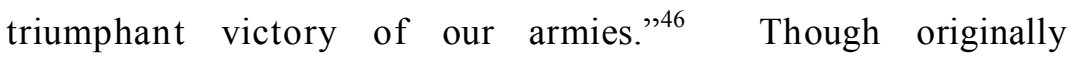
constructed of plaster and intended to be temporary, it was

\footnotetext{
${ }^{44}$ Hynes, 270

${ }^{45}$ Ibid, 269

${ }^{46}$ Penelope Curtis. "The Whitehall Cenotaph: An Accidental Monument" Imperial War Museum Review 9 (1994) 33

Past Imperfect 14 [2008) | ( ) |ISSN 1711-053X| elSSN 1718-4487
} 
enthusiastically accepted as a treasured civic symbol and focus for diverse kinds of individual mourning, eventually recreated in stone and described as a "world-famous" monument. ${ }^{47}$

Lutyens' triumphal design emphasized collective strength and banished the thought of national failure. ${ }^{48}$ Its success relied upon a traditional vocabulary of images and symbols associated with mourning, through which different forms of bereavement could be mediated and assured. ${ }^{49}$ Iconographic simplicity and symbolic 'blankness' allowed civic memorials to accept, contain and represent nearly any form of sentiment. ${ }^{50}$ In that respect, these civic memorials in Portland stone, marble and bronze were a great leveler and unifier of the various feelings and experiences shared by the British population following the war. Their visual and symbolic emptiness may have also helped to ease anxiety and guilt felt by returning survivors for the loss of friends and the slaughter of enemies.

Though it was a central part of the soldier's training and action in battle, signs of violence or aggression in memorial figures were carefully avoided. Troubling thoughts of how servicemen met their deaths, or caused the deaths of others, were politely avoided by idealized and often static figures, usually

${ }^{47}$ A Pictorial and Descriptive Guide to London and its Environs. (London: Ward, Lock \& Co. Ltd., c.1922) 65

${ }^{48}$ Michael Rowlands, "Remembering to Forget: Sublimation as Sacrifice in War Memorials" The Art of Forgetting. Adrian Forty and Susanne Kuchler, eds. (Oxford: Berg Books, 1999) 131

${ }^{49}$ Winter, Sites of Memory, Sites of Mourning: The Great War in European Cultural History. (Cambridge: University Press, 1995) 223

${ }^{50}$ King, "Remembering and Forgetting in the Public Memorials of the Great War" The Art of Forgetting. Adrian Forty and Susanne Kuchler, eds. (Oxford: Berg Books, 1999) 161 
pictured at rest. ${ }^{51}$ Artists and architects attempting to form an appropriate vocabulary of memorial imagery faced considerable difficulties in reconciling this divide.

Locally erected street shrines contrasted the austerity, simplicity and uniformity of Lutyens' design and his followers. Erected at corners and various avenues of local neighbourhoods, 102| these memorials appeared on a smaller scale and displayed a greater variety of treatment than the national and civic commemorative forms. ${ }^{52}$ During 1914-1918, street shrines became focuses of civilian attention and acted as talismans for citizens whose family members were involved in fighting; they were also symbolic of community life and street culture. ${ }^{53}$ Their aesthetic variety and unique construction share more characteristics with trench art than with officially sanctioned public memorial projects.

Much of this spontaneous and independent community memorial construction boom resulted from dissatisfaction with the lack of imagery in official memorials, and replied specifically to the Imperial War Graves Commission's reluctance to use overt Christian symbolism in cemeteries overseas. ${ }^{54}$ With very little room offered for personalization of grave markers, the Commission was accused of preferring economical design over the efforts and personalities of individual soldiers. ${ }^{55}$ Equal treatment

\footnotetext{
${ }^{51}$ Ibid, 152-54

${ }^{52}$ Bilton, 107

${ }^{53}$ Mark Connelly, The Great War, Memory and Ritual: Commemoration in the City and East London, 1916-1939. (Suffolk: Boydell Press, 2002) 25

${ }^{54}$ Moriarty, "Christian Iconography and First World War Memorials" Imperial War Museum Review 6 (1991) 66

${ }^{55}$ With hundreds of thousands of servicemen to memorialize, individual expression for each was practiacally impossible. See Michael Hefferman, "For Ever England: The Western Front and the politics of remembrance in Britain"
}

$$
\begin{gathered}
\text { Past Imperfect } \\
14 \text { [2008) | (C) |ISSN 1711-053X | elSSN 1718-4487 }
\end{gathered}
$$


of war casualties was officially considered inevitable given the sheer number and dispersion of bodies.

Charles Jagger's Royal Artillery memorial was also the subject of public debate, most of which revolved around its central depiction of a howitzer in white marble. While welcoming comments on the technical accuracy of his work, Jagger would not be swayed on the more general question as to whether or not an artillery piece was suitable as a memorial focal point. ${ }^{56}$ Civilian concerns that it might too closely recall the harsh horrors of war were overridden by Jagger's interest in publicly commemorating the work and sacrifices of artillerymen, with which he was personally familiar. Amid the controversy, some critics praised the howitzer's symbolism and its commemorative permanence. ${ }^{57}$ As the work of gunners faded into memory, Jagger's controversial sculpture attempted to unify civilian and military experience by placing an accurately reproduced yet demobilized (and unserviceable) weapon in the middle of London. By incorporating an accurate representation of weaponry in a memorial intended for the expression of grief and admiration, Jagger's work tended towards the type of layered meaning accomplished by trench art objects which also transformed battlefield remnants and trophies into new mnemonic forms.

Despite the occasional disagreement, the British public generally conceded that projects for public commemoration were necessary and valuable. The equal popularity of Lutyen's

Ecumene 2:3 (1995) 302; Sarah Tarlow, “An Archaeology of Remembering: Death, Bereavement and the First World War" Cambridge Archaeological Journal 7:1 (1997) 112

${ }^{56}$ Ibid, 118

${ }^{57}$ Sir H. Uniacke in The Times, 23 October 1925 
Cenotaph (an empty tomb) and the Grave of the Unknown Warrior (a ceremonially filled one) indicated that memorial variety was acceptable. ${ }^{58}$ While public commemoration of the war appealed to individual memory, it also had to serve the nation in order to produce a cohesive experience of community remembrance. The challenge of coupling collective mourning 104 with private reminiscence was equally serious for museums, which occupied a hybridized role of institutional memory maker and steward of material culture after the war. ${ }^{59}$ This was a particularly serious issue for the Imperial War Museum, where the acquisition and display of artifacts related with the First World War persistently involved contact with and confusion over trench art objects.

\section{Bethlem and Belgium: Artifacts of War}

By 1914, museums were widely regarded as a force for public good and a sign of civilized society in Britain. Though England lacked an official military museum at the outbreak of hostilities that year, collections of war relics and trophies from historic conflicts existed in the Royal Artillery Collections, Tower of London, and Royal United Services Museum. A 1918 illustrated guide to London described the latter as an "interesting though somewhat

${ }^{58}$ Bob Bushaway, "Name Upon Name: The Great War and Remembrance" in Myths of the English. Roy Porter, ed. (Cambridge: Polity Press, 1992) 153; Moriarty, "Private Grief and Public Remembrance: British First World War Memorials" in War and Memory in the Twentieth Century. (Oxford: Berg Books, 1997) 125

${ }^{59}$ King. "Remembering and Forgetting" 147; Moriarty, "The Material Culture of Great War Remembrance” Journal of Contemporary History 34:4 (1999) 655; Stephen Heathorn, "The Mnemonic Turn in the Cultural Historiography of Britain's Great War" The Historical Journal 48:4 (2005) 1104

Past Imperfect

14 [2008] | (C) |ISSN 1711-053X | eISSN 1718-4487 
miscellaneous collection" including fragments of Zeppelins and various objects captured from German troops during the war. ${ }^{60}$ That year, the London museum featured an exhibit of similar items obtained by civilians on British soil. Governments often encouraged military-themed exhibitions of a sufficiently positive tone as a way of boosting public morale and support for the war. ${ }^{61}$

The First World War was at the very least a 'setback' for

the British Museum, which faced closure and appropriation by war-related organizations from 1916-1918. ${ }^{62}$ While Prime Minister David Lloyd George described the use of museum space by government and military bodies as "one of the many lamentable necessities of war," he faced a torrent of public opposition to the suggestion. ${ }^{63}$ Public outcry following these proposals affirmed that museums were considered important sites for research, education, leisure, recreation and moral well-being in Britain well before the outbreak of war. ${ }^{64}$ The argument to keep these institutions open was more than museum-friendly propaganda: from 1914-1918, the Museum of Natural History and Museum of Practical Geology fielded inquiries on finding supplies of fresh water, the food value of bird's eggs, horse musculature, and insect vectors of disease. ${ }^{65}$ Many materials and artifacts held in museum collections were turned to significant national benefit in wartime.

\footnotetext{
${ }^{60}$ Findlay Muirhead, ed. London and its Environs. (London: Macmillan \& Co., 1918) 67

${ }^{61}$ Robb, 137

${ }^{62}$ Arundell Esdaile, The British Museum Library: a short history and survey.

(London: George Allen \& Unwin Ltd., 1946) 160

${ }^{63}$ Museums Journal 17 (1917-18) 13

${ }^{64}$ Gaynor Kavanagh, Museums and the First World War: A Social History.

(London: Leicester University Press, 1994) 42

${ }^{65}$ Ibid, $62-63$

$$
\begin{gathered}
\text { Past Imperfect } \\
14 \text { [2008]| (@) |ISSN 1711-053X| | ISSN 1718-4487 }
\end{gathered}
$$
}


Furthermore, numerous local and national museums housed travelling displays on infant welfare and nutrition that echoed government efforts to educate the public. ${ }^{66}$ Examples of the 'New War Dinner' and techniques of digging trenches for gardens published in illustrated newspapers at the time were reflected in exhibitions on new approaches to food and domestic 106 farming techniques. The 'museum as educator' was conceived of before $1914 ;{ }^{67}$ but the scale with which disparate efforts to inform civilians and alter their daily behavior were brought together in museum spaces was unprecedented during the war. By 1918, formerly "dusty" and questionably useful exhibition spaces were becoming "the centres of new life." 68

After the war, however, a crisis of confidence in these new functions occurred and museums reverted to a more distant style of curatorship. "The practices in which museums had engaged to serve the needs of the home front were excused as one-off initiatives, to which there was now no need to return." ${ }^{99}$ By the outbreak of the Second World War, museum professionals were more concerned with the protection of collections than public outreach. The British Museum's closure in 1916 and subsequent removal of major pieces to an underground tube station caused such rapid deterioration that an official department of conservation was established and continued through the post-war period at the museum. ${ }^{70}$ Conservation studies, training and

\footnotetext{
${ }^{66}$ Winter, The Great War and the British People, 191

${ }^{67}$ Henry Cole expressed his belief that museums could educate adults in the 1880s. Quoted in Kavanagh, 12

${ }^{68}$ Museums Journal 17 (1918) 160

${ }^{69}$ Kavanagh, 160-63; Museums Journal 19 (1919) p.36 for questions re: proper jurisdiction of museums

${ }^{70}$ Kavanagh, 34
} 
facilities vastly improved following that experience of relocation and the realization of how quickly artifacts could deteriorate in unfavourable environmental conditions.

Another consequence of the war on museums in Britain was the foundation of a National War Museum on 5 March, 1917. Later renamed the Imperial War Museum, this institution was plagued with debate from the beginning over whether it could also function as a national war memorial. Sir Martin Conway expressed the hope that "the very heart and focus of the building should be of a memorial character," since "no pile of sculpture wherever set up could possibly vie in public interest or truly memorial character with this Hall and Gallery of Honour in the heart of a great War Museum."71 The initially modest project soon ballooned to an ambitious plan for a building with glass courts and a 'Hall of Remembrance' situated on 11 acres and at a cost of $£ 665,000$. Remarkably, the projected cost was initially dismissed as insignificant, considering the project's importance: "the question of cost should not be too closely considered; the one essential is to ensure that the building to be erected shall be worthy of those whose sacrifices it is intended to commemorate." 72 Unfortunately, the carnage of Passchendaele caused significant anxiety over devoting such a large site and sum to a war that might be better forgotten, and the memorial function was officially dropped in 1917. Debate dragged on and progress flagged, with the IWM opening temporarily in Burlington House in 1918 and then the Crystal Palace in 1920, which was by then a struggling tourist attraction from a bygone

${ }^{71}$ Quoted in Kavanagh, 134

${ }^{72}$ Museums Journal 17 (1918) 173-74; The Times, 5 April 1918

Past Imperfect
14 [2008) | @ |ISSN 1711-053X | elSSN 1718-4487 
era of optimism and faith in technology as the instrument of progress.

The Crystal Palace incarnation, though praised by the King at its opening in 1920, was a farcical disaster for some artifacts: tanks and artillery pieces left sitting outside were subject to vandalism and so ravaged by the elements they eventually had 108 to be scrapped. Inside, displays faced temperature fluctuations, leaks, theft and crowding among potted plants and entertainments including a menagerie, syncopated orchestra, pleasure fair and fireworks. ${ }^{73}$

The Crystal Palace location was also heavy with irony. As the site of the world's first large-scale and international exhibit of industrial products intended to further social and commercial development, ${ }^{74}$ the Crystal Palace offered a darkly meaningful home to machines produced by industry for the sole purpose of destruction. Succeeding years did not do much to improve displays, which sat surrounded by relics of the original $19^{\text {th }}$ century exhibitions: it was "a splendid hodge-podge of everything that had been saved...with the dummy parachutist and the sniper's tree getting dustier and more ghastly" $" 75$ as time went by. Lack of adequate storage space continued to be a problem though the collections were pruned and moved to new galleries at the Science Museum of South Kensington.

Gaynor Kavanagh has suggested that the Imperial War Museum's failure to procure adequate funds for its originally

\footnotetext{
${ }^{73}$ Paul Cornish, "'Sacred Relics': Objects in the Imperial War Museum, 191739" in Matters of Conflict, 42; The Times, 28 May 1920

${ }^{74}$ Celeste Olalquiaga, The Artificial Kingdom: A Treasury of the Kitsch Experience. (New York: Pantheon Books, 1998) 31

${ }^{75}$ Jones and Howell, 155

Past Imperfect 14 [2008] | (C) |ISSN 1711-053X | elSSN 1718-4487
} 
ambitious memorial plans demonstrates that it was founded more in an effort to keep up spirits than through a genuine desire to commemorate the war experience. ${ }^{76}$ Similar concerns were expressed by J.L. Myres in 1919 with his criticisms that war museums equated to war-mongering and a failure to account for the value of human history in times of peace. ${ }^{77}$ Yet although its intention to be a national memorial was never realized, the Imperial War Museum maintained its claims to popularity even as the Great War faded from fashionable conversation. Relocation to the old Bethlem Hospital (a former mental asylum) in 1936 finally gave the Imperial War Museum a permanent home. The additional irony of this location, given that tens of thousands of British veterans were suffering 'shell-shock' at the time, was tactfully avoided in coverage of opening day ceremonies. ${ }^{78} \mathrm{~A}$ 1936 guide to London suggested the site among a list of destinations for a two-day walking tour, described it as one of the "first magnitude" sights in the city, and further noted that it was founded "as a memorial of the effort and sacrifice made by men and women of the Empire during the Great War of 1914-1918.,"79 Though not officially sanctioned as a civic or national memorial, the museum came to be perceived as such.

If the Imperial War Museum was not to be an official memorial, it could at least retain and record memorial efforts underway throughout Britain. Curator Charles ffoulkes requested the sphinx from atop Lutyens' Cenotaph along with fragments of

\footnotetext{
${ }^{76}$ Kavanagh, 122

${ }^{77}$ J.L. Myres, "If a War Museum, Why Not a Peace Museum?” Museums Journal 19 (1919) 73

${ }^{78}$ The Times, 7 July 1936

${ }^{79}$ A Pictorial and Descriptive Guide to London. (London: Ward, Lock \& Co. Ltd., 1936) 44, 257
}

\footnotetext{
Past Imperfect
14 [2008] | @ | ISSN 1711-053X | elSSN 1718-4487
} 
the original plaster structure. ${ }^{80} 1925$ saw an entire exhibit devoted to drawings and photographs of memorials from all over the United Kingdom and theatres of war, and unique commemorations were achieved on a small scale through individual displays that commemorated lives lost in the war effort. ${ }^{81}$ Memorialization within the museum continued as it 110 marked significant anniversaries from the First World War with special displays and advertisements in the Press. ${ }^{82}$ These varied efforts at commemoration in the post-war years fed in to perceptions of the Imperial War Museum as a site of national memory. Despite these initiatives, however, trench art acquisitions were seldom included in public exhibitions.

The process of collecting war-related material began relatively late in Britain; by 1915 , Germany had already formed several repositories and the Allies were scrambling to keep up. ${ }^{83}$ As stores and depots for war trophies began to appear near the battle fronts, trench art and small-scale souvenirs were also collected. Museums have struggled to assimilate and categorize trench art in their collections since then, and although these items were often acquired, they have seldom been displayed. ${ }^{84}$ Charles Madeley warned against them as "relics of no personal or local

\footnotetext{
${ }^{80}$ Curtis, 34; Remnants of the original Cenotaph were placed in the museum in 1926, and a small ceremony held during Armistice Day of that year. See Museums Journal 26 (1926) 186

${ }^{81}$ Cornish, 46

${ }^{82}$ Curator Charles ffoulkes reminded the public of the anniversary of ' $L$ ' battery and that the gun was housed at the Imperial War Museum in an article dated 1 September, 1922.

${ }^{83}$ Kavanagh, 105

${ }^{84}$ The Times of 16 September 1927 announced the acquisition of a candlestick made from a German sword twisted and broken at Cologne, but made no further discussion of similar items on display.
} 
interest... commonly called souvenirs and sometimes trophies" that were 'dangerous' because of their tendency to indicate "the abnormal rather than the typical, and so cease to be historical." ${ }^{\prime 85}$ Sir Arthur Leetham's list of desirable artifacts for war museums focused primarily on the weapons of war and their categorization, ${ }^{86}$ with little room for small-scale objects associated with the life of soldiers outside of battle. And Sir

Henry Howarth declared the purpose of museums to be "not entirely the exhibition of bizarre and eccentric specimens to arouse wonder and curiosity." 87 The varied character of trench art made by and for soldiers, of souvenirs purchased at the front, and of war kitsch produced in Britain refused to fit neatly into established forms of museum categorization. Consequently, many evocative and historically significant items were relegated to museum vaults. In the years immediately following the First World War, private and personal domestic spaces offered the only consistent opportunity to display and discuss trench art objects.

\section{Home: Exhibition vs. Exile}

After the chaos of 1914-1918, domesticity was idealized and sought with renewed fervor throughout Britain. ${ }^{88}$ A culture of home ownership and 'consumer durables' remained from the late $19^{\text {th }}$ century and the expansion of affordable suburban housing after the war encouraged people to retain souvenirs and mementos

\footnotetext{
${ }^{85}$ Charles Madeley, "Local War Museums” Museums Journal 18 (1918) 64

${ }^{86}$ Museums Journal 18 (1918) 94

${ }^{87}$ Museums Journal 19 (1919) 24

${ }^{88}$ Winter, The Great War and the British People, 264
} 
related to family experience and history as never before. ${ }^{89}$ The production of cheap, consumable goods in factories ensured that the early $20^{\text {th }}$ century "was an age for THINGS." 90

Gwinell wrote in 1919 that the First World War would go down in history as a "War of Souvenirs."91 He appears to have been right, for there is ample evidence that soldiers picked up and 112| retained souvenirs of battle. A photograph of Royal Fusiliers celebrating the capture of Thiepval in 1916 shows men wearing German helmets and holding revolvers up to the camera. ${ }^{92}$ The War Illustrated published photos of soldiers 'souveneering' in 1914, and dead bodies were often found stripped of items either kept or sold by other soldiers. Captain P.H. Rawson wrote in 1916 of a button he cut off of a German's body with his own hands as a present for home, ${ }^{93}$ and Stanley Spencer's The Resurrection of the Soldiers in the chapel at Burghclere depicted servicemen being happily reunited with beloved items lost in the chaos of battle. ${ }^{94}$ Souveneering was even undertaken by FieldMarshal Haig and the Royal Family. ${ }^{95}$ Taken together, it expressed a "determination to find a heaven in the hell of war" 96

\footnotetext{
${ }^{89}$ Paul Todman, The Great War: Myth and Memory. (London: Hambledon Continuum, 2005) 70, 215, 229

${ }^{90}$ Jones and Howell, 7

${ }^{91}$ Gwinell, quoted in Trench Art, 129-30

${ }^{92}$ Todman, unnumbered

${ }^{93}$ Letter from Captain P.H. Rawson dated 8 March, 1916 quoted in Saunders, Trench Art, 131

${ }^{94}$ Spencer's work featured a Bible, given by 'sister Flo.'

${ }^{95}$ The Times of 12 June 1922 reported a gift of personal affects and souvenirs from Field-Marshal Haig including a railway spike, barometer and Zulu stick. War souvenirs from the Royal Family were also donated to the museum, including bomb fragments from the Zeppelin raids on London; see The Times, 15 October 1937

${ }^{96}$ Kitty Hauser, Stanley Spencer. (New Jersey: Princeton University Press, 2001) 66
}

\author{
Past Imperfect \\ 14 [2008) |@ |ISSN 1711--053X| elSSN 1718-4487
}


and became a cohesive and binding element for many individuals struggling through the fragmentary experience of war.

Trade in war materials was active and prevalent through the Western Front both during and after the War. W.N. McClean wrote in 1917 that after entering a town just left by 'Fritz', "I got

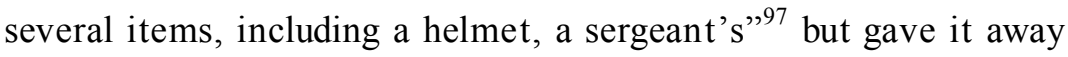
before realizing its commercial worth. Belgian and French civilians also searched for German bullets and salvaged copper from the battlefields to support struggling local economies in peacetime. $^{98}$ Though the association with war tourism was distasteful to him, possession of souvenirs could equally be nostalgic, bitter-sweet, and romantic through their association with experience and memory. Souvenirs made coherent "in personal and small-scale terms, an important event which seemed confused, spasmodic and incoherent to most of the individuals who took part in it." 99 Few experiences were as confused, spasmodic and incoherent as that of the Western Front in the First World War, and small-scale mementos became an important element of capturing and conveying events that were difficult for participants to explain.

Collecting souvenirs is a way of marking where one has been; visitors to new places seldom venture far without the purpose of buying souvenirs. ${ }^{100}$ In a war zone characterized by devastated battlefields, souveneering offered the chance for

\footnotetext{
${ }^{97}$ Mills Research Collections, W.N. McClean Fonds

${ }^{98}$ Lloyd, 23; Webster, 43

${ }^{99}$ Susan M. Pearce, "Objects as meaning: or narrating the past" Interpreting Objects and Collections. Susan M. Pearce, ed. (London: Routledge, 1994) 20

${ }^{100}$ Michael Hitchcock, "Introduction” in Souvenirs: The Material Culture of Tourism. Michael Hitchcock and Ken Teague, eds. (Aldershot: Ashgate, 2000)

6
}

$$
\begin{gathered}
\text { Past Imperfect } \\
14 \text { [2008]| (@) |ISSN 1711-053X| | ISSN 1718-4487 }
\end{gathered}
$$


soldiers to retain some form of identity. The act of collecting also required future activities like interpretation, assemblage and reflection and therefore implied a hope for survival. ${ }^{101}$ Some souvenirs had nothing to do with the experience of battle directly, but rather related to the disjointed experience of being in a place far from home. Embroidered silk postcards represented the use of 114 cottage industries by soldiers to procure beautiful and exotic items to send to loved ones. Their colourful flowers and romantic messages were "an extreme example of a way to escape the ugliness of war at the front"102 and "hid from home the filth of the mud trenches and the stench of death that surrounded the men on a daily basis."103 Ultimately, private collections of souvenirs forged a link between families and combatants, helped to unify the civilian and soldier experience, and circumvented the ugly realities of war.

On the home front, kitsch and popular art objects also masked the difficulties of combat by making war materiel seem like a comfortable aspect of daily life. ${ }^{104}$ While they could never fully embody the total war experience, small commemorative items available for sale did achieve some form of recognition and understanding through "a piercing, fragmentary recollection [of] our individual memories." ${ }^{105}$ Some items made traumatic events more manageable and nearly quaint, as in brooches made of aluminum from wrecked Zeppelins. Other objects walked a fine

\footnotetext{
${ }^{101}$ Pearce, "The Urge to Collect" in Interpreting Objects and Collections, 158

102 Pat Tomczysyn, “A Material Link Between War and Peace: First World War silk postcards" in Matters of Conflict, 124

${ }^{103}$ Tomczysyn, "With Love From the Trenches: Embroidered Silk Postcards of the First World War" Material History Review 51 (2000) 48

${ }^{104}$ Robb, 174

${ }^{105}$ Olalquiaga, 71
} 
line between whimsy and morbidity, from pickelhaube inkwells to Lord Kitchener door knockers, tank-shaped jewelry boxes, cigarette lighters, pin cushions and monopoly pieces, ceramic incendiary bombs and rifle-shaped toast racks.

Heraldic china was perhaps the most widespread of all war kitsch items and enjoyed a 'collecting craze' that lasted until the Great Depression. W.H. Goss began the manufacture of these white, glazed figures emblazoned with various crests in the late$19^{\text {th }}$ century, and popular items during the First World War included 'Tommies', factory workers, nurses, gas masks, hats and caps, and a wide variety of tanks. Miniature reproductions of civic memorials were also popular and often inscribed with commemorative phrases. ${ }^{106}$ Not only could miniatures of national monuments be brought into the home, but domestic items like a grandfather clock or hearth could similarly be 'heraldized' into memorials in their own right. These china objects achieved a significant union between forms of public remembrance in civic space and the nature of private commemoration in the domestic sphere.

Trench art objects and war souvenirs were often treated as relics and intermediaries between the visible and invisible world of experience and death, signifying important relationships and events from a chaotic past. ${ }^{107}$ The ubiquitous artillery shell was previously discussed as a force for destruction and fragmentation on both the home and battle fronts. Its transformation into

\footnotetext{
${ }^{106}$ Robert Southall, Take Me Back to Dear Old Blighty: The First World War through the eyes of the Heraldic China Manufacturers. (Horndean: Milestone Publications, 1982) 97

${ }^{107}$ Krzysztof Pomian, "The collection: between the visible and the invisible" in Interpreting Objects and Collections, 167 
trench art and souvenir forms, however, allowed spent shells to successfully bridge the gap of experience between men and women, soldiers and civilians, individuals and industrialized society, the living and the dead in war. ${ }^{108}$ Soldiers brought home innumerable shell cases as souvenirs, and china manufacturers copied a huge variety for display and use in the home. ${ }^{109}$ They 116 were perfect mementos, whose "emptiness would always resound the loss of the real experience of war and the secrets of the Front, only decipherable by fellow veterans."110 Once placed in the home, however, civilians could attempt to close this distance by rituals of polishing similar to those undertaken by servicemen in caring for their kit. Spent ammunition was often transformed into aesthetic and symbolic items like crucifixes, aircraft, and civic emblems. Engraving and etching rendered the shells useless as a weapon of war and reclaimed their materiality for domestic remembrance.

Some soldiers commissioned craftsmen to reshape shells entirely; in some parts of Belgium, this practice evolved into a cottage industry that endured after the war's close. ${ }^{111}$ Artifacts from the First World War, particularly those manufactured by participants in the war effort or battlefield experience, could outlast their creators and become "the vehicle by which persons [transcended] their own temporal limits."

\footnotetext{
${ }^{108}$ Saunders, "The ironic "culture of shells", 22

${ }^{109}$ Ibid, 34; Southall, 61

${ }^{110}$ Gygi, 79

${ }^{111}$ Saunders, "Bodies of Metal, Shells of Memory: 'Trench Art' and the Great

War Recycled" Journal of Material Culture 5:1 (2000) 49

${ }^{112}$ Daniel Miller, "Artefacts and the Meaning of Things" Companion

Encyclopedia to Anthropology: Humanity, Culture and Social Life. Tim Ingold, ed. (London: Routledge, 1994) 409
}

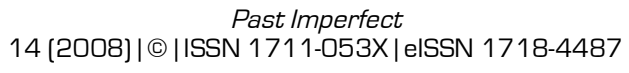


important aspect of structuring, retelling, and encapsulating one's own war experience.

Scrapbooks made by individuals during and after the war similarly encapsulated unique experiences in material form. E. Cooke's autograph book from nursing at the 56 General Hospital in 1917 is both an intensely personal memento and a reflection on work that employed thousands of women during the First World War. ${ }^{113}$ A photo postcard kept by C.W. Berry from Dunkerque marked with hand-drawn arrows shows where he was standing when a bomb struck nearby, and notes that he was able to salvage some pieces of the wrecked weapon. ${ }^{114}$ C.F. Healey provided a similar record of individual experience within a common frame by annotating a group photo with "wounded-deadgas-dead-dead-missing," and situated the image between battles at Messines and Passchendale. ${ }^{115}$ All of these items helped to process, communicate and encapsulate one's personal experience and memories of war in relation to the national historical narrative.

Soldiers tended to collect small items while at the front and assemble them into trench art pieces once home ${ }^{116}$ much like a three-dimensional form of scrapbooking. Others might produce objects and send them home at particularly compelling moments: John Scollen, filled with a sense of dread on the eve of his approach to the Somme, sent a cross made of bullets to his wife

\footnotetext{
${ }^{113}$ Mills Research Collections, Album \#50

${ }^{114}$ Mills Research Collections, C.W. Berry Fonds

${ }^{115}$ Mills Research Collections, C.F. Healey Fonds; Orders issued to W.G. Smith were similarly marked with a note about their issuance "previous to going into battle at Neuves Chapelle March 10, 1915.” Mills Research Collections, W.G. Smith Fonds

${ }^{116}$ Saunders, Trench Art, 83
} 
with the inscription, "GOODBYE GOODBYE and think of me in your prayers...I made the cross myself." "117 He did not survive the advance. A soldier's gift of souvenirs might even transcend the grave: Hereward Carrington told of a séance wherein a soldier ghost demanded that his mother wear a penny found on the Western Front around her neck. ${ }^{118}$

118

\section{Assembly: Action and Reaction}

Given the fragmentary nature and massive scale of destruction on the Western Front, trench art and war souvenirs functioned in homes and museums to unify otherwise disparate elements and portray the First World War experience with greater totality to civilians and relatives. Greater appreciation of these objects in museum collections is now beginning to occur: in 1998, the Imperial War Museum mounted an unconventional exhibition called 'The First World War Remembered' composed entirely of personal mementos, souvenirs and memorabilia. Ignoring the iconic canvases of Nash and Sargent hanging nearby, crowds of visitors pored over the humble items on display, trying to read every word and occasionally crying. ${ }^{119}$ Jay Winter, in writing on his experience of work for the war museum at Péronne, emphasized the importance of this kind of plurality and flexibility because "historical debates move on," and so too should museum

\footnotetext{
${ }^{117}$ Letter to wife dated 27 June, 1916 quoted in ibid, 102

${ }^{118}$ Hereward Carrington, Psychical Phenomena and the War. (New York:

Dodd, Mead and Co., 1918) 275

${ }^{119}$ Michel Barret, "The Great War and Post-Modern Memory" New Formations 41 (2000) 138
}

Past Imperfect 
techniques. ${ }^{120}$ Trench art offers valuably intricate layers of meaning - from the unique accounts of how items were assembled to their troubled place in museological practice - and functions as a reminder of the complex interplay between private and public experiences of war. While cenotaphs lurk stoically in public squares and await annual commemorations, the dynamism of trench art represents a novel intersection between the material culture of war and its conceptual significance.

${ }^{120}$ Winter, Remembering War: The Great War Between Memory and History in the Twentieth Century. (New Haven: Yale University Press, 2006) 236-37

Past Imperfect 14 [2008) | @ |ISSN 1711-053X| elSSN 1718-4487 